Journal of Research in Nursing

Vol. 1, No. 1, 2015

Print ISSN 2244-2723

University of Cebu

Cebu City, Cebu, Philippines

\title{
Traits and Empowerment of Team Leaders
}

\author{
Marian M. Sawit \\ Mauro Allan P. Amparado
}

\section{Abstract}

This study determined the traits and empowerment of the team leaders of the College of Nursing, University of Cebu Banilad, Cebu City, Cebu, Philippines. The research utilized descriptivecorrelational design with 90 clinical instructors as participants. A researcher-made questionnaire was used to collect data. Statistical treatment used were weighted mean, hypothetical mean range, and chi-square Test of Independence.

The leadership traits of the subjects in terms of managerfollower relationship is partially exhibited while the task structure proved to be moderately structured. The manager power is moderately powerful since some of the basic functions of a manager has been employed. In terms of empowerment of the team leaders, it was interpreted as mostly empowered.

In conclusion, the study revealed that there is no significant relationship between leadership traits and empowerment.

Recommended citation: Sawit, M. M. \& Amparado, M. A. P. (2015). Traits and Empowerment of Team Leaders. Journal of Research in Nursing, 1(1), 70-79. 